\title{
DETERMINANTS OF JOB SEEKERS TO SELECT RECRUITMENT AGENCY FOR NEW JOB VACANCIES
}

\author{
By Phan Xuan Binh ${ }^{1}$ and Nguyen Minh $\mathrm{Ha}^{2}$
}

The most important determinant of organizational effectiveness is the ability to attract, hire, and develop capable talent. The ability to attract and retain superior employees can lead to sustained competitive advantage for organizations. This is difficult due to the shrinking availability of qualified labor. The use of recruitment agency (RA) or employment agency allows human resource departments to target and identify quality candidates with more efficiency. RA, kind of consultancy, is normally understood as third party recruiter that finds jobs for people seeking them and finds people to fill particular jobs ${ }^{3}$. Some RA focus their efforts on executive, managerial, and professional positions (white and yellow collar workers). These firms are split into two groups: (1) contingency firms that charge a fee only after a candidate has been hired by a client company and (2) retainer firms that charge a client a set fee whether or not the contracted search is successful. Most of RA in Vietnam apply contingency basis.

Majority of foreign and big local companies use $R A$ as one of the key recruitment sources to attract middle to senior level employees despite there is maybe higher expenses of this source than using other recruitment sources in some extents below:

- The job vacancy is top confidential and recruiter cannot launch the public recruitment

- The vacancy requires very short time to fill

- The limited staffing resources of recruiting department or

- The limited candidate pool in some industries or function which may cause very long time to fill the vacancy or to find out the right candidate

Keywords: recruitment agency; job seeker; job vacancies; recruitment consultant

\section{Introduction}

The research objectives are to identify what factors influence job seekers to select recruitment agency in Ho Chi Minh city when they look for new jobs and to suggest some recommendations for improving performance and quality of service. Data base is collected through two steps (1) qualitative research by face - to - face interviews to job seekers and group discussion to recruitment specialists (2) Quantitative research conducted by questionnaire. The main method is quantitative.

\section{Literature Review}

\section{Definitions}

Jobseekerorjobapplicantorcandidate is defined as who is actively looking for a job. Job seeker may be an unemployed or on-the-job person. Job seeker in this article only focuses on white and yellow collar workers.

Recruitment sources: Recruitment can focus on the internal labor market (i.e., pursuing staff already employed by the organization) or the external labor market (i.e., pursuing applicants from outside the organization). Internal candidates can be recruited through internal job postings, word-of-mouth, or internship programs. Organizational practices used to recruit from external labor markets include employment advertising, employee referral programs, job fairs, college campus recruitment, employment agencies, rehiring former employees, or networking (Zottoli \& Wanous, 2000)

\footnotetext{
${ }^{1}$ MBA Co- program between Solvay Brussels School and HCMC Open University. Head of Recruitment, Supply Chain - FirstAlliances - Executive Search \& Selection Firm.

${ }^{2}$ Ho Chi Minh City Open University

${ }^{3}$ The American Heritage ${ }^{\circledR}$ Dictionary of the English Language, 2000
} 
Recruitment agency or employment agency: Dessler (2002) had clearly defined three types of employment agencies: (1) public agency operated by government; (2) agencies associated with nonprofit organization; (3) privately owned agencies.

Private employment agencies are important sources of clerical, white-collar and managerial personnel. Most are fee paid job in which employers pay the fee. They charge fees for each vacancy they place. Executive recruiters or Executive Search and Selection agency are special RA retained by employers to seek out top management talent for their clients. Executive Search and Selection agencies only focus their efforts on executive, managerial, and professional positions. In the scope of this research, the service of Executive Search \& Selection is analyzed.

\section{Theory of choices}

Mankiw, Gans and King (2002) had explained some principles influenced individual making decisions:

\section{Principle 1 - People face trade-offs:}

Making decisions requires trading off one goal against another. This principle is considered in the context of job seekers those currently have a job or receive more than one job offer. For the former case, they only face trade-offs between their current job and new job. The latter case requires he/ she has to consider all job offers and finally accept only one. For all situations, job seeker may be stopped their tenure during probation period and become jobless. It's obvious that to gain the benefit of new offer as more attractive remuneration package, higher position, new knowledge exchange, better working location, etc... Job seeker has to trade off his/ her job security and other obvious benefits.

\section{Principle 2 - The opportunity cost:}

The opportunity cost is the cost of something what you give up to get that item. When making decision, decision makers should be aware of the opportunity costs that accompany each possible action. When job seekers look for new job openings, the opportunity cost is time, money and efforts he/ she has to spend to search information, prepare application documents and attend interviews. Other invisible cost which is difficult to measure is the privacy to be disclosed during the interview. Most of the recruiters are aware of their responsibilities and commitment to keep the candidate's information confidentially. However, they can't promise totally to follow this rule due to the job change of their staffs who involve to recruitment process.

\section{the margin}

Principle 3 - Rational people think at

A rational decision maker takes an action if and only if the marginal benefit of the action exceeds the marginal cost. This principle is the consequence of these above principles if applying to job seekers' behavior. As we have explained the opportunity cost of job seeker when trading off their current job for new job vacancies, job seekers consider to choose kind of recruitment sources which cost them less and bring more benefit than other sources. Furthermore, job seekers who handle high level positions are much afraid of revealing privacy. For them, referrals, headhunting or recruitment agency are more trustworthy sources than walk-ins; to post their resume on online recruitment website or directly applying.

\section{Principle 4 - People respond to incentive}

People make decisions by comparing costs and benefits, their behavior may change when the cost and benefit change. People change their behavior in respond to the incentive they face. Job seekers will choose which recruitment sources can offer to them higher benefit for the same level of job or they can use less resources to gain the offer. They also consider which sources they can get higher probability of job offer. 


\section{Theory of Customer Behavior}

Sheth \& Mittal (2004) classified products and services into different sectors. Recruitment services belong to business sector including management training and consulting services, employment benefits services, etc.

Regarding to the roles of customer, also Sheth \& Mittal (2004) stated that customer can play three different roles in the marketplace transaction: User, Buyer and Payer.

The user is the person who actually consumes or uses the products or receives the benefits of the services. In recruitment agency, job seeker can be classified as User. About the reasons for role specification, Lack of Time and Free from service fee can be discussed to feature why a certain group of labor forces choose RA when seeking for new job.

All customer behavior is driven by needs and wants, by the value received through the use, the acquisition of products or services. Theory of customer behavior explains why services value, service quality are key factors which recruitment services have to focus on to attract job seekers.

\section{Research Methodology and Findings}

\section{Research Methodology}

Target of the research is white and yellow collar workers currently working for nongovernmental, FDI, big local organizations in Ho Chi Minh city. The targets have at least 03 years experience, salary range VND 6 to 50 Million per month. The convenient sampling method is applied. There is 148 valid responds. A questionnaire with 29 items aim to find out job seekers' assessment of job vacancies; recruitment agencies and recruitment consultant characteristics and influences to their attention and selection RA when searching new job. Questionnaire uses Likert 05 scales. Research result is analysed by
Exploratory Factor Analysis (EFA) method, measurement of scales tested by Cronbach Apha value. After 02 times of analysing data by Varimax rotation technique, 04 constructs are eliminated.

The result of qualitative research shows that there are 25 variables groups into 04 key factors influence to the selection of RA by job seekers when searching new job vacancies:

1. Job vacancy characteristics \& attractiveness: The usefulness and transparency of information in regard to vacancy profile; Challenging job; Highpaid job; Preferred working location; Convenience of job location

2. Recruitment agency characteristics: RA has experienced consultants; Strong customer - base and well-known clients(recruiters); High frequency of updated information on website; Usefulness of the tests; Career consultancy; Usefulness of consultancy services; Quality of consultancy services; High fill rate; Time to fill a vacancy; Satisfaction to new offer.

3. Recruitment consultant's competences: Experience of consultants; Recruitment skill of consultants; Conversation skill; Foreign language skill; Appearance and grooming; Consult to candidate appropriate information about vacancy and recruitment procedure and quick feedback and advise appropriate information/ next steps for candidates

4. Convenience of interview by $R A$ : Place of the interview; Time of the interview; Duration of the interview

Factors influence job seekers to select recruitment agencies for new job vacancies

The result of EFA shows that there are 04 key factors, in which 02 factors divided into 02 sub groups, influence to the selection of RA by job seekers when searching new job vacancies. 
Table 1

Factor loading result

\begin{tabular}{|c|c|c|c|c|c|}
\hline \multirow[b]{2}{*}{ Factor 1} & \multirow[b]{2}{*}{ Job vancancy characteristics \& attractiveness } & \multicolumn{4}{|c|}{ Factor loading } \\
\hline & & 1,000 & 2,000 & 3,000 & 4,000 \\
\hline VA1 & $\begin{array}{l}\text { The usefulness and transparency of information in } \\
\text { regard to vacancy profile. }\end{array}$ & 0,663 & & & \\
\hline VA2 & Challenging job & 0,837 & & & \\
\hline VA3 & High-paid job & 0,789 & & & \\
\hline VA4 & Preferred working location & 0,799 & & & \\
\hline VA5 & Convenience of job location & 0,661 & & & \\
\hline Factor 2 & Recruitent agency characteristics & & & & \\
\hline 2.1 & Recruitment consultant influences & & & & \\
\hline QD2 & RA has experienced consultants & & 0,837 & & \\
\hline QD6 & $\begin{array}{l}\text { Strong customer - base and well-known clients } \\
\text { (recruiters) }\end{array}$ & & 0,814 & & \\
\hline QD7 & High frequency of updated information on website & & 0,578 & & \\
\hline 2.2 & Services and efficiency quality & & & & \\
\hline QD8 & Usefulness of the tests & & 0,516 & & \\
\hline QD9 & Career consultancy & & 0,868 & & \\
\hline QD10 & Useful of consultancy services & & 0,846 & & \\
\hline QD11 & Quality of consultancy services & & 0,861 & & \\
\hline QD12 & High fill rate & & 0,723 & & \\
\hline QD13 & Time to fill a vacancy & & 0,752 & & \\
\hline QD14 & Satisfaction to new offer & & 0,642 & & \\
\hline Factor 3 & Recruitment consultant's competences & & & & \\
\hline 3.1 & Recruitment consultant's influences & & & & \\
\hline $\mathrm{RC} 1$ & Experience of consultants & & & 0,744 & \\
\hline $\mathrm{RC} 2$ & Recruitment skill of consultant & & & 0,858 & \\
\hline $\mathrm{RC} 3$ & Conversation skill & & & 0,679 & \\
\hline $\mathrm{RC} 4$ & Foreign language skill & & & 0,626 & \\
\hline $\mathrm{RC5}$ & Appearance and grooming & & & 0,627 & \\
\hline 3.2 & Recruitment consultant and compliances & & & & \\
\hline $\mathrm{RC} 6$ & $\begin{array}{l}\text { Consult to candidate appropriate information about } \\
\text { vacancy and recruitment procedure }\end{array}$ & & & 0,941 & \\
\hline $\mathrm{RC7}$ & $\begin{array}{l}\text { Quickly feedback and advise appropriate } \\
\text { information/ next steps to candidates }\end{array}$ & & & 0,937 & \\
\hline Factor 4 & Convenience of interview by RA & & & & \\
\hline IT1 & Place of the interview & & & & 0,854 \\
\hline IT2 & Time of the interview & & & & 0,913 \\
\hline IT3 & Duration of the interview & & & & 0,653 \\
\hline
\end{tabular}




\section{Factor 'Recruitment Agency} Characteristics' is considered as the most important factor. This result is rationale and logic if considering the advantages versus disadvantages of many recruitment sources on the viewpoint of job seekers. When coordinating to RA, job seekers benefit the consultancy services. They are provided appropriate information about the vacancy, employer. Besides, recruitment consultant advises them how to leverage their pro and improve their cons to increase the probability to be offered. Another important thing is to assess the correlation between new vacancies to candidate's career development, objective. Recruitment consultant with consistent and details information of employer, strong recruitment competences can provide efficient advice. These reasons prove that variable 'Career consultancy', 'Quality of consultancy services' and 'RA has experienced consultants' are the highest important assessment of job seekers regarding to their overall evaluation of RA' characteristics.

\section{Factor 'Convenience of interview by $R A$ '}

Referring the some models of recruitment and selection procedure, interview is the second step after candidate's resume is screened and invited to interview. All candidates are obviously aware of the high probability to be interviewed if their resume sent to recruiter from RA. Some standard operational key performance Indicators (KPI) practiced by RA:

- 3:1 is ratio between shortlisted candidates versus 01 vacancy

- 5:3 is ratio between total candidates interviewed versus to be shortlisted (they are qualified to introduce to recruiter)

- $2: 3$ is ratio between candidates are $01^{\text {st }}$ interviewed by recruiter on total 03 shortlisted candidates
From the above ratio, we can estimate that if job seekers are invited to interview by RA, they have at least $20 \%$ probability to be interviewed by recruiter. This ratio is extremely high if comparing to the application on online recruitment website ${ }^{4}$. Higher convenience of interview is absolutely an advantage for RA to approach their job seekers and attract them to be their candidates.

Variable 'Time of the interview' and 'Place of the interview' is highly concerned by job seekers. This result is a point for recruitment consultants consider when arranging interview, especially who handle supply chain - logistics segment.

\section{Factor 'Recruitment consultant 'competences}

This factor is very correlation to other factor 'Recruitment Agency Characteristics' and Factor 'Convenience of interview by RA'.

RA controls services quality by well systematic operational procedures, ERP system and qualified experienced manpower. The compliances of recruitment consultants gain the highest concerns of job seekers. Job seekers highly appreciate the details information and feedbacks about the vacancy, recruitment procedure and results of interviews by both RA and employers.

Compare to other recruitment sources, job seekers if applying through RA receive details feedback from recruiter. They are recognized their strength their suitability, then they accept their weakness and improve it. Variable 'RA has experienced consultants' is also high concerns of job seekers. One of the influences of RA to job seekers is the strong customer-base and customers' reputation. This result proves that RA can differentiate its influences by setting up exclusively partnership to some key customers who have their significant reputation and maintain strong relation to other big recruiters.

\footnotetext{
${ }^{4}$ Reference: number of viewers versus job openings posted on www.vietnamworks.com dated Dec 10th 2010
} 
Factor 'Job vacancy characteristics and attractiveness'

It's not surprised when job seekers assess the influences of this factor to their $j$ selection of RA is less important than other 03 factors. If the recruiters are not exclusive client, the vacancy is posted on many recruitment sources. So the attractiveness of vacancy belongs to how job seekers assess vacancy's challenge ('Challenging job'). Item 'Preferred working place' is also an important concern which attracts the intention.

Table 2

\section{Cronbach Alpha value of each factor}

\begin{tabular}{|c|c|c|}
\hline Factor name & Items & $\begin{array}{l}\text { Cronbach's } \\
\text { Alpha }\end{array}$ \\
\hline \multirow{5}{*}{$\begin{array}{l}\text { Factor 1: } \\
\text { Job vancancy } \\
\text { characteristics \& } \\
\text { attractiveness }\end{array}$} & $\begin{array}{l}\text { VA1 The usefulness and transparency of information in regard to } \\
\text { vacancy profile }\end{array}$ & \multirow{5}{*}{$\mathbf{0 , 8 0 7}$} \\
\hline & VA2 Challenging job & \\
\hline & VA3 High-paid job & \\
\hline & VA4 Preferred working location & \\
\hline & VA5 Convenience of job location & \\
\hline \multirow{10}{*}{$\begin{array}{l}\text { Factor 2: } \\
\text { Recruitent agency } \\
\text { characteristics }\end{array}$} & QD2 RA has experienced consultants & \multirow{10}{*}{0,876} \\
\hline & QD6 Strong customer - base and well-known clients (recruiters) & \\
\hline & QD7 High frequency of updated information on website & \\
\hline & QD8 Usefulness of the tests & \\
\hline & QD9 Career consultancy & \\
\hline & QD10 Useful of consultancy services & \\
\hline & QD11 Quality of consultancy services & \\
\hline & QD12 High fill rate & \\
\hline & QD13 Time to fill a vacancy & \\
\hline & QD14 Satisfaction to new offer & \\
\hline \multirow{7}{*}{$\begin{array}{l}\text { Factor 3: } \\
\text { Recruitment } \\
\text { consultant' } \\
\text { competences }\end{array}$} & RC1 Experience of consultants & \multirow{7}{*}{0,849} \\
\hline & RC2 Recruitment skill of consultant & \\
\hline & RC3 Conversation skill & \\
\hline & RC4 Foreign language skill & \\
\hline & RC5 Appearance and grooming & \\
\hline & $\begin{array}{l}\text { RC6 Consult to candidate appropriate information about vacancy and } \\
\text { recruitment procedure }\end{array}$ & \\
\hline & $\begin{array}{l}\text { RC7 Quickly feedback and advise appropriate information / next steps } \\
\text { to candidates }\end{array}$ & \\
\hline \multirow{3}{*}{$\begin{array}{l}\text { Factor 4: } \\
\text { Convenience of } \\
\text { interview by RA }\end{array}$} & IT1 Place of the interview & \multirow{3}{*}{0,866} \\
\hline & IT2 Time of the interview & \\
\hline & IT3 Duration of the interview & \\
\hline
\end{tabular}


Table 3

Reliability test results ranking by descending importance

\begin{tabular}{|c|c|c|c|c|c|c|c|}
\hline & & $\begin{array}{l}\text { Sample } \\
\text { size }\end{array}$ & Min & Max & Mean & $\begin{array}{c}\text { Std. } \\
\text { Devia- } \\
\text { tion }\end{array}$ & $\begin{array}{l}\text { Factor } \\
\text { loading }\end{array}$ \\
\hline Factor 3.2 & $\begin{array}{l}\text { Recruitment consultant and } \\
\text { compliances }\end{array}$ & 148 & 1 & 5 & 4,243 & 0,784 & \\
\hline RC6 & $\begin{array}{l}\text { Consult to candidate appropriate } \\
\text { information about vacancy and } \\
\text { recruitment procedure }\end{array}$ & & & & & & 0,941 \\
\hline $\mathrm{RC} 7$ & $\begin{array}{l}\text { Quickly feedback and advise } \\
\text { appropriate information/ next steps to } \\
\text { candidates }\end{array}$ & & & & & & 0,937 \\
\hline Factor 1 & $\begin{array}{l}\text { Job vancancy characteristics \& } \\
\text { attractiveness }\end{array}$ & 148 & 1 & 5 & 4,062 & 0,502 & \\
\hline VA2 & Challenging job & & & & & & 0,837 \\
\hline VA4 & Preferred working location & & & & & & 0,799 \\
\hline VA3 & High-paid job & & & & & & 0,789 \\
\hline Factor 2.1 & Recruitment consultant influences & 148 & 2 & 5 & 4,018 & 0,571 & \\
\hline QD2 & RA has experienced consultants & & & & & & 0,837 \\
\hline QD6 & 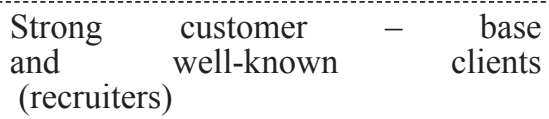 & & & & & & 0,814 \\
\hline QD7 & $\begin{array}{l}\text { High frequency of updated information } \\
\text { on website }\end{array}$ & & & & & & 0,578 \\
\hline Factor 3.1 & Recruitment consultant's influences & 148 & 2 & 5 & 3,805 & 0,502 & \\
\hline $\mathrm{RC} 2$ & Recruitment skill of consultant & & & & & & 0,858 \\
\hline $\mathrm{RC} 1$ & Experience of consultants & & & & & & 0,744 \\
\hline $\mathrm{RC} 3$ & Conversation skill & & & & & & 0,679 \\
\hline $\mathrm{RC} 5$ & Appearance and grooming & & & & & & 0,627 \\
\hline $\mathrm{RC} 4$ & Foreign language skill & & & & & & 0,626 \\
\hline Factor 2.2 & Services and efficiency quality & 148 & 2 & 5 & 3,786 & 0,606 & 148 \\
\hline QD9 & Career consultancy & & & & & & 0,868 \\
\hline QD11 & Quality of consultancy services & & & & & & 0,861 \\
\hline QD10 & Useful of consultancy services & & & & & & 0,846 \\
\hline QD13 & Time to fill a vacancy & & & & & & 0,752 \\
\hline QD12 & High fill rate & & & & & & 0,723 \\
\hline QD14 & Satisfaction to new offer & & & & & & 0,642 \\
\hline QD8 & Usefulness of the tests & & & & & & 0,516 \\
\hline Factor 4 & Convenience of interview by RA & 148 & 2,333 & 5 & 3,478 & 0,544 & \\
\hline IT2 & Time of the interview & & & & & & 0,913 \\
\hline IT1 & Place of the interview & & & & & & 0,854 \\
\hline IT3 & Duration of the interview & & & & & & 0,653 \\
\hline
\end{tabular}


Independent sample $t$-test conducted for 02 different responses working in services and supply chain / logistics shows that there is statically significant in assessing the influence and importance of factor - 'Convenience of interview by RA' by Supply Chain / Logistics respondents. In HoChiMinh city, most of $03^{\text {rd }}$ party logistics companies set up warehouse system outside central city or suburbs. So job seekers who work in this industry are difficult to arrange interview with recruitment agency within working hours or 01 hour after work due to distant travel. To successfully arranging interview with them, recruitment consultant has to be flexible in time and place of interview even interview scheduled on weekend. Candidates who work in services are more flexible in interview if they are invited.

Table 4

Statistics on Independent -Samples T-Test - Factor 4

\begin{tabular}{|l|l|c|c|}
\hline \multicolumn{2}{|l|}{} & \multicolumn{2}{|c|}{ Factor 4 } \\
\cline { 2 - 4 } $\begin{array}{l}\text { Levene's Test for Equality } \\
\text { of Variances }\end{array}$ & F & 1,196 & $\begin{array}{c}\text { Equal variances not } \\
\text { assumed }\end{array}$ \\
\hline \multirow{4}{*}{ T test } & Sig. & 0,277 & \\
& T & $-2,236$ & $-2,170$ \\
& Df & 96 & 77,365 \\
& Sig. (2-tailed) & $\mathbf{0 , 0 2 8}$ & $\mathbf{0 , 0 3 3}$ \\
& Mean Difference & $-0,248$ & $-0,248$ \\
& Std. Error Difference & 0,111 & 0,114 \\
\hline
\end{tabular}

Table 5

Variable's mean in Factor 4

\begin{tabular}{|c|c|c|c|}
\hline & & Services & Logistics/ Supply Chain \\
\hline QD20 & Place of the interview & 3,43 & 3,55 \\
\hline QD21 & Time of the interview & 3,38 & 3,70 \\
\hline QD22 & Duration of the interview & 3,29 & 3,59 \\
\hline
\end{tabular}

\section{Recommendations}

\section{Solution 1: Setting up standard to} "filter clients"

Most of RA have set up and practiced standard operation procedure (SOP) to control their services quality, especially in qualifying candidates. However, standard to "select" clients (recruiters) is not common practiced. Unqualified clients may cause strong impact to the reputation and services of RA and lead to low efficiency because clientsignore some procedures in recruitment and selection such as providing interviews' feedback; cancelling the job order without clear explanation or inconsistent in their requirements.
Solution 2: Enhancing the quality of recruitment consultants

RA focuses on the quality of career consultancy by enhancing the manpower force. Hard skills of consultants as their knowledge, experience and ethics should be considered as 'must' requirement because soft skills (communication, negotiation, presentation, etc) can be trained in short term.

Solution 3: Communicate "Value proposition"

Value proposition can be considered to apply for this service in order to change the perception of majority of job seekers who never think of using this service or 
do not trust on the value of this service. Communicating the benefit of time saving, free consultancy and convenience RA can offer to job seekers versus other recruitment sources.

\section{References:}

Antonides \& Raaij F.V (1998),"Theory of consumer behavior", John Wiley \& Sons.

Barber, A.E (1998), "Recruitment Employees: Individual and Organizational Perspectives", Thousand Oaks, California, 91320: Sage Publications Inc.

Breaugh, J.A(1992), "Recruitment: Science and Practice". Boston:Kent:PWSKENT Publishing Company.

Breaugh, J.A; Starke, M (2000), "Research on Employee Recruitment: so many studies, So many remaining questions", Journal of management, 26(3).

Canava, R.Y; Delahaye B.L \& Sekaran. U (2001), "Applied Business Research", John Wiley \& Son Australia.

Dessler, G (2002), “A framework for Human Resources Management - Steps in Recruitment and Selection process", Prentice Hall, NY

Hatcher,L.(1994), “Astep-by-step approach to using the $S A S(R)$ system for factor analysis and structural equation modeling", Cary, NC: SAS Institute.

Hoàng Trọng; Chu Nguyễn Mộng Ngọc (2008), "Phân tích dĩ liệu nghiên cứu với SPSS", Trường Đại học Kinh tế Thành phố Hồ Chí Minh, NXB Hồng Đức.

Huỳnh Gia Xuyên (2010), "Nghiên cứu các yếu tố ảnh hưởng đến việc sinh viên chọn trường Đại hoc Mờ TP.HCM", Luận văn thạc sĩ kinh tế, Trường Đại học Mở thành phố Hồ Chí Minh.

Foxall, G.D (2003), "The behavior analysis of consumer choice", Journal of Economic Psychology, 24 (5).
Gorsuch, R.L (1983), "Factor Analysis", Hillsdale: Lawrence Erlbaum Associates.

Lin, B. \& Stasinskaya, V.S. (2002), " Data warehousing management issues in online recruiting", Human Systems Management, 21, 1-8.

Mankiw, N; Gans, J; King, Sing (2002), "Principles of Microeconomics", Thomson, Australia.

Marr, E.R (2007), "E-Recruitment: The effectiveness of the internet as a recruitmentsource", MasterofBusiness thesis, School of Management, Faculty of Business, Queensland University of Technology

Mathis R.L; Jackson. JS (2005), "Human Resources Management". It is available at website http://www.citehr. com/111557-changing-nature-humanresource-management-e-book.html

Nunnally, J.O (1978), "Psychometric Theory, New York: McGraw-Hill.

Pallant, J (2005), "SPSS survival manual", Allen \& Unwin, Australia

Rynes, S. L (1991), "Recruitment, Job choice and Post-hire consequences: A call for new research directions" In Dunnette, M.D., \& Hough, L. M. (Eds.), Handbook of industrial and organizational psychology $\left(2^{\text {nd }}\right.$ ed.), Vol. 2: 399-444. Palo Alto, CA: Consulting Psychologists Press.

Rynes, S. L, Bretz, R \& Gerhart, B (1991), "The importance of recruitment in job choice; A different way of looking", Personnel Psychology 44

Salkind, N.J (2006), "Exploring research", Upper Saddle River, N.J.: Prentice Hall.

Schein, EH (1987), "The Clinical Perspective in Fieldwork", Thousand Oaks, CA: Sage.

Sheth M, Mittal B (2004), "Customer Behavior: A Management 
Perspective", Mason, Ohio: Thomson/ South-Western.

Tabachnick, B.G; Fidell, L.S (2001), “Using multivariate statistics", Needham Heights, MA: Allyn and Bacon.

Turban, D. B., Forret, M. L., \& Hendrickson, C. L. (1998), "Applicant attraction to firms: Influences of organization reputation, job and organization attributes, and recruiter behaviors", Journal of Vocational Behavior, 52, 24-44.
The American Heritage ${ }^{\circledR}$ Dictionary of the English Language (2000), Houghton Mifflin Harcourt

Webster, A.L (1998), “Applied Statistics for Business and Economics: An Essential version", Irwin/McGraw-Hill, USA

Zottoli, M. \& Wanous, J. (2000), "Recruitmentsourceresearch: Current status and future directions", Human Resource Management Review, 10(4) 